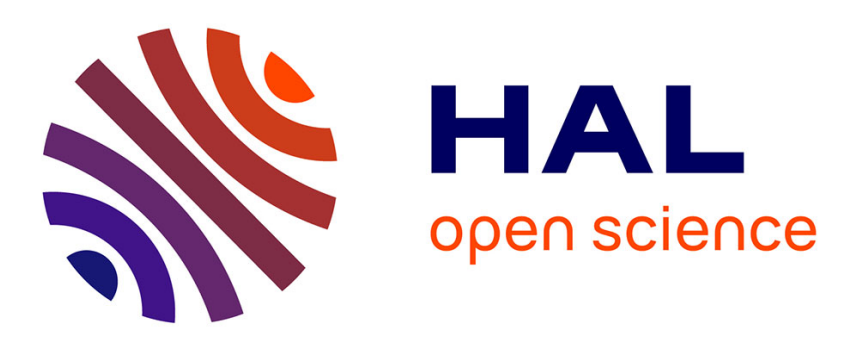

\title{
Controlling Photooxygenation with a Bifunctional Quinine-BODIPY Catalyst: towards Asymmetric Hydroxylation of $\beta$-Dicarbonyl Compounds
}

Jérôme Fischer, Lucas Mele, Hélène Serier-Brault, Pierrick Nun, Vincent Coeffard

\section{To cite this version:}

Jérôme Fischer, Lucas Mele, Hélène Serier-Brault, Pierrick Nun, Vincent Coeffard. Controlling Photooxygenation with a Bifunctional Quinine-BODIPY Catalyst: towards Asymmetric Hydroxylation of $\beta$-Dicarbonyl Compounds. European Journal of Organic Chemistry, 2019, 2019 (37), pp.6352-6358. 10.1002/ejoc.201900984 . hal-02376249

\section{HAL Id: hal-02376249 \\ https://hal.science/hal-02376249}

Submitted on 25 Nov 2020

HAL is a multi-disciplinary open access archive for the deposit and dissemination of scientific research documents, whether they are published or not. The documents may come from teaching and research institutions in France or abroad, or from public or private research centers.
L'archive ouverte pluridisciplinaire HAL, est destinée au dépôt et à la diffusion de documents scientifiques de niveau recherche, publiés ou non, émanant des établissements d'enseignement et de recherche français ou étrangers, des laboratoires publics ou privés. 


\title{
Controlling Photooxygenation with a Bifunctional Quinine-BODIPY Catalyst: Towards Asymmetric Hydroxylation of $\beta$-Dicarbonyl Compounds
}

\author{
Jérôme Fischer, ${ }^{[a]}$ Lucas Mele, $^{[a]}$ Hélène Serier-Brault, ${ }^{[b]}$ Pierrick Nun, ${ }^{[a]}$ Vincent Coeffard ${ }^{*[a]}$
}

\begin{abstract}
We report herein a new catalytic strategy towards asymmetric photooxygenation of $\beta$-dicarbonyl compounds. Our method is based on the synthesis of a bifunctional photosensitizer composed of a quinine organocatalyst grafted to a iodo-BODIPY framework capable of generating singlet oxygen. The quinine moiety serves both to interact with the substrate for promoting photooxygenation and to deactivate singlet oxygen in the absence of substrate. The bifunctional photosensitizer prepared was subsequently applied in the asymmetric oxygenation of a series of $\beta$-dicarbonyl compounds under green light irradiation. Control experiments and kinetic analyses were carried out to shed the light on the mechanism.
\end{abstract}

\section{Introduction}

Light-driven catalysis is a thriving field of research owing to the synthetic potential of this strategy in organic chemistry. ${ }^{[1]}$ In efforts to design new catalytic systems, the combination of photochemistry and asymmetric catalysis has been emerging as a relevant and efficient strategy by which chirality can be introduced into molecular architectures. ${ }^{[2]}$ Within this context, the induction of chemical processes under light illumination is triggered either by photoinduced electron transfer or energy transfer. While asymmetric visible light-induced electron transfer has been applied in a range of synthetic transformations in the past decade, the concept of asymmetric energy transfer photocatalysis has received less attention. ${ }^{[3]}$ The recent works in this field have mainly focused on enantioselective [2+2] photocycloadditions and asymmetric photooxygenation reactions via singlet oxygen generation. ${ }^{[4]}$ Singlet oxygen $\left({ }^{1} \mathrm{O}_{2}\right)$ is the first excited state of molecular oxygen which can be generated under light irradiation by triplet-triplet energy transfer between an excited photosensitizer and ground state triplet oxygen. ${ }^{[5]}$ The high electrophilicity of singlet oxygen makes this oxidant very reactive towards a multitude of substrates. For instance, photooxygenation is a leading method for heteroatom oxidation, ${ }^{[6]}$ [4+2] and [2+2] cycloaddition to form endoperoxides, ${ }^{[7]}$ ene reaction ${ }^{[8]}$ and dearomatization of electron rich aromatic compounds such as phenols ${ }^{[9]}$ and furans. ${ }^{[10]}$ While singlet oxygen

\footnotetext{
[a] J. Fischer, L. Mele, Dr. P. Nun, Dr. V. Coeffard University of Nantes, CEISAM UMR CNRS 6230, F-44000, Nantes France.

E-mail: vincent.coeffard@univ-nantes.fr

[b] Dr. H. Serier-Brault

Institut des Matériaux Jean Rouxel, Université de Nantes, CNRS, 2 rue de la Houssinière, BP 32229, 44322 Nantes - France.
}

Supporting information for this article is given via a link at the end of the document has found numerous applications in the construction of densely functionalized architectures, ${ }^{[11]}$ control over absolute stereochemistry in the addition of singlet oxygen still remains a challenging task. Pioneering works in introducing chirality involved cyclodextrin-porphyrins catalytic systems. ${ }^{[12]}$ Very low levels of enantioselection were obtained for these systems in photooxygenation of alkenes. Following on from these studies, most of the reported strategies lie in the combination of a chiral catalyst for substrate activation and a photosensitizer aiming at generating singlet oxygen under light. For example, the combination of enamine catalysis and photosensitization was studied for the asymmetric oxygenation of aldehydes and ketones at the $\alpha$-position. ${ }^{[13]}$ Diverse aminocatalysts were investigated leading to the corresponding products with variable results in terms of enantiomeric excesses. In addition, the synthetic appeal of this strategy suffers from the low stability of enamine intermediates and/or aminocatalysts towards singlet oxygen. In 2012, the group of Gao described enantioselective photooxygenations by phase-transfer catalysis. ${ }^{[14]}$ The authors focused their work on the hydroxylation of a series of indanoneand tetralone-derived $\beta$-keto esters and $\beta$-keto amides. ${ }^{[15]}$ Besides organocatalytic strategies, the group of Xia reported in 2017 the preparation of bifunctional photocatalysts for enantioselective aerobic oxidation of $\beta$-keto esters, mainly derived from indanone. ${ }^{[16]}$ In-situ complexation of the bisoxazoline ligand with $\mathrm{Ni}(\mathrm{acac})_{2}$ enabled the formation of the desired oxygenated products in high yields and excellent enantioselections. In light of the previous works, an important impediment to developing asymmetric photooxygenation lies in possible background racemic processes lowering the enantioselectivity levels. ${ }^{[17]}$ This is particularly the case for substrates which do not require any activation such as alkenes involved in ene-hydroxylation or diene systems for the formation of endoperoxides through [4+2] cycloaddition. In order to tackle the challenge of asymmetric photooxygenation, we planned to design novel catalytic systems for which the chiral moiety would play a dual role (Figure 1). Thus, it would direct the enantioselective photooxygenation (ON mode) and would deactivate singlet oxygen into triplet state when the substrate does not interact with the chiral system (OFF mode). Within the broader field of science, the design of photosensitizers able to deliver singlet oxygen in a controlled way is a tremendous research field with applications both in organic synthesis and in photodynamic therapy. ${ }^{[18]}$ To put this strategy into practice, we turned our attention to the Cinchona alkaloids which are privileged structures in asymmetric catalysis. In addition, the group of Zanocco have demonstrated that Cinchona alkaloids, cinchonidine, cinchonine, quinine and quinidine, are physical quenchers of singlet oxygen through a 


\section{General asymmetric photooxygenation strategy}

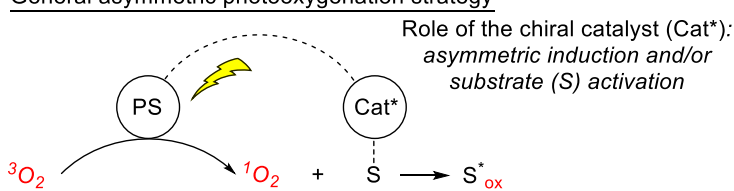

This work: ON/OFF photooxygenation

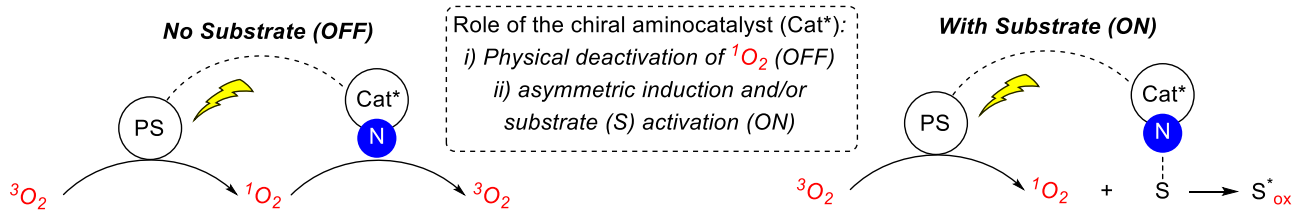

Figure 1. Asymmetric photooxygenation strategies.

charge transfer mechanism between the quinuclidine nitrogen and singlet oxygen. ${ }^{[19]}$ Inspiring studies by the group of Melchiorre have shown that quinine could promote an asymmetric conjugate addition of methyl-2-oxo-1-indanecarboxylate 1 to maleimides in chloroform with high enantiomeric excesses. ${ }^{[20]}$ In light of these works, we conjectured that quinine would play both the role of singlet oxygen quencher and organocatalytic promoter.

\section{Results and Discussion}

First, we elected to use 1,3-dicarbonyl compound 1 as a model substrate and quinine as a chiral catalyst (Table 1). To assess whether photooxygenation of $\mathbf{1}$ could be achieved without quinine, we chose iodo-BODIPY 2 as a photosensitizer owing to its ability to efficiently promote photooxidative transformation. ${ }^{[21]}$ After the photooxygenation step, a triphenylphosphine reducing protocol was carried out to transform the hydroperoxide function into the alcohol 3 which was isolated in $50 \%$ yield (entry 1 ). Therefore, this result shows that no activation is required for the photooxygenation of $\mathbf{1}$ underlining the challenging task to conduct an asymmetric version of this reaction. The reactions with 2 and 5 mol\% of quinine $(Q)$ were then investigated and the best results were obtained with $5 \mathrm{~mol} \%$ of quinine (entries $2 \& 3$ ). In this example, careful analysis of the crude by ${ }^{1} \mathrm{H}$ NMR showed that alcohol 3 was formed without any traces of the corresponding hydroperoxide product. Therefore, the reductive work-up with triphenylphosphine was not carried out when using quinine. Increasing the catalytic loading of quinine led to a slight decrease of enantioselectivities and switching from chloroform to another aprotic solvent such as toluene has no influence on the results (entries 4-6). Slightly lower enantioselections were observed by decreasing the amount of $\mathbf{2}$ or by increasing the reaction concentrations (entries $7 \& 8$ ). The use of TPP did not improve the results (entry 9). Therefore, the best conditions involve 5 mol\% of quinine and chloroform as the solvent (entry 3). Based on these results, we then screened a series of Cinchona-derived catalysts in order to study the structural influence on the reaction outcome (Scheme 1).
Table 1. Photooxygenation of 1 catalyzed by 2 and quinine. ${ }^{[a]}$.

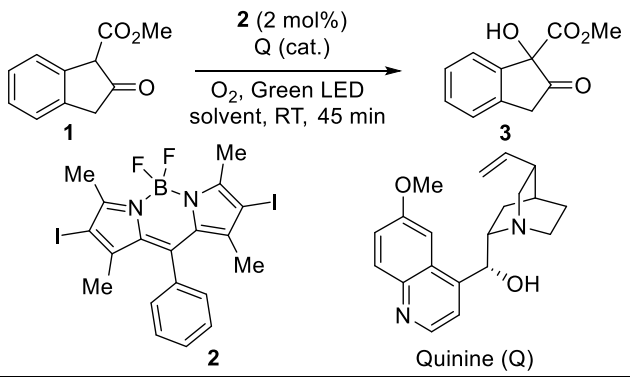

\begin{tabular}{llll}
\hline Entry ${ }^{[a]}$ & Conditions & Yield (\%) & ee ${ }^{[\mathrm{b}]}$ \\
\hline 1 & No Quinine, $\mathrm{CHCl}_{3}^{[\mathrm{cc}]}$ & 50 & n.d. \\
2 & $\mathrm{Q}(2 \mathrm{~mol} \%), \mathrm{CHCl}_{3}$ & 33 & n.d. \\
3 & $\mathrm{Q}(5 \mathrm{~mol} \%), \mathrm{CHCl}_{3}$ & 83 & 38 \\
4 & $\mathrm{Q}(10 \mathrm{~mol} \%), \mathrm{CHCl}_{3}$ & 73 & 25 \\
5 & $\mathrm{Q}(10 \mathrm{~mol} \%), \mathrm{Toluene}$ & 67 & 25 \\
6 & $\mathrm{Q}(20 \mathrm{~mol} \%), \mathrm{CHCl}_{3}$ & 32 & 12 \\
7 & $\mathrm{Q}(5 \mathrm{~mol} \%), \mathrm{CHCl}_{3}^{[\mathrm{dd}]}$ & 69 & 34 \\
8 & $\mathrm{Q}(5 \mathrm{~mol} \%), \mathrm{CHCl}_{3}^{[\mathrm{e}]}$ & 89 & 33 \\
9 & $\mathrm{Q}(5 \mathrm{~mol} \%), \mathrm{CHCl}_{3}^{[\mathrm{f}]}$ & 61 & 36 \\
\hline
\end{tabular}

[a] Reaction conditions unless otherwise noted: 1 (0.21 mmol), 2 (2 mol\%), $\mathrm{O}_{2}$, Green LEDs, solvent $(4.2 \mathrm{~mL}), \mathrm{RT}, 45 \mathrm{~min}$. n.d.: not determined. [b] Enantiomeric excesses were determined by chiral HPLC. [c] $\mathrm{PPh}_{3}(0.21$ mmol) was added at the end of the reaction. [d] $1 \mathrm{~mol} \%$ of 2 . [e] $2.1 \mathrm{~mL}$ of $\mathrm{CHCl}_{3}$. [f] 2 mol\% of TPP (tetraphenylporphyrin) was used instead of 2.

Commercially available cinchonidine gave similar levels of yields and enantioselectivities as the quinine catalyst. A lower level of enantiomeric excess for $\mathbf{3}$ was obtained with quinidine while the opposite enantiomer was obtained as the major product in the cinchonine-catalyzed photooxygenation. Quinine gave the best results both in terms of yield and enantioselectivity and this 


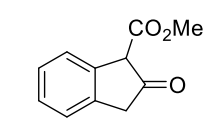

1<smiles>C=CC1CC2CCN1CC2[C@H](O)c1ccnc2ccc(OC)cc12</smiles>

Quinine (Q) Yield $=83 \%$ ee $=38 \%$

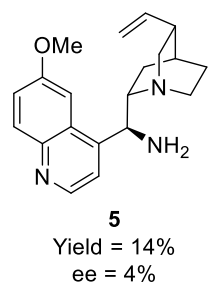

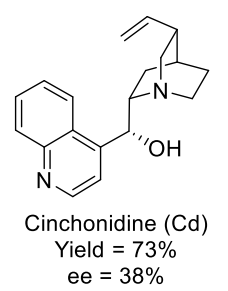

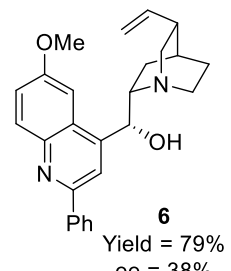

ee $=38 \%$
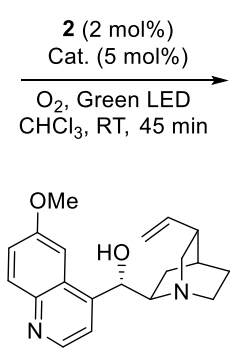

Quinidine (Qd) Yield $=75 \%$ ee $=16 \%$<smiles>CCC1CN2CCC1C2[C@H](OC)c1ccnc2ccc(OC)cc12</smiles><smiles>CC(=O)C1(O)C(=O)Cc2ccccc21</smiles>

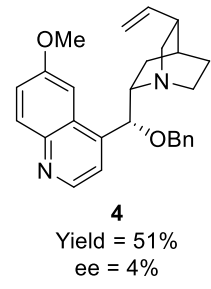<smiles>CC(C)c1cc(-c2ccccc2)cc(C(C)C)c1-c1ccccc1</smiles>

$(\mathrm{DHQ})_{2} \mathrm{Pyr}$

Yield $=62 \%$ ee $=-24 \%$

Scheme 1. Cinchona-derived catalyst screening.

prompted us to investigate the functionalization of the quinine moiety for the photooxygenation. Substitution of the alcohol by a benzyl group (structure 4) had a negative impact on the enantioselection. Photooxygenation of $\mathbf{1}$ catalyzed by $\mathbf{4}$ afforded the product in $51 \%$ yield and $4 \%$ ee. This result shows the importance of the free hydroxyl function in transferring the chiral information. Very low yields and enantioselectivities were observed for the photooxygenation of $\mathbf{1}$ in the presence of the catalyst $\mathbf{5}$. In order to increase the steric hindrance around the hydroxyl group, the derivative 6 was prepared and was tested in the photooxygenation but no improvement was observed compared to quinine. The anthraquinone-bridged catalyst, $(\mathrm{DHQ})_{2} \mathrm{AQN}$, and the pyrimidine-based $(\mathrm{DHQ})_{2} \mathrm{Pyr}$ were also examined providing compound 2 in $76 \%$ and $62 \%$, respectively albeit with low enantioselectivities. From the catalyst screening, the best reaction conditions involve the use of $5 \mathrm{~mol} \%$ of quinine with $2 \mathrm{~mol} \%$ of iodo-BODIPY 2. In efforts to improve the enantioselectivities, we surmised that connecting the photosensitizer 2 to the quinine could lower the background racemic photooxygenation by bringing in close proximity the source of singlet oxygen and the quencher. The synthetic route towards bifunctional photocatalyst $\mathbf{1 1}$ is described in Scheme 2 .

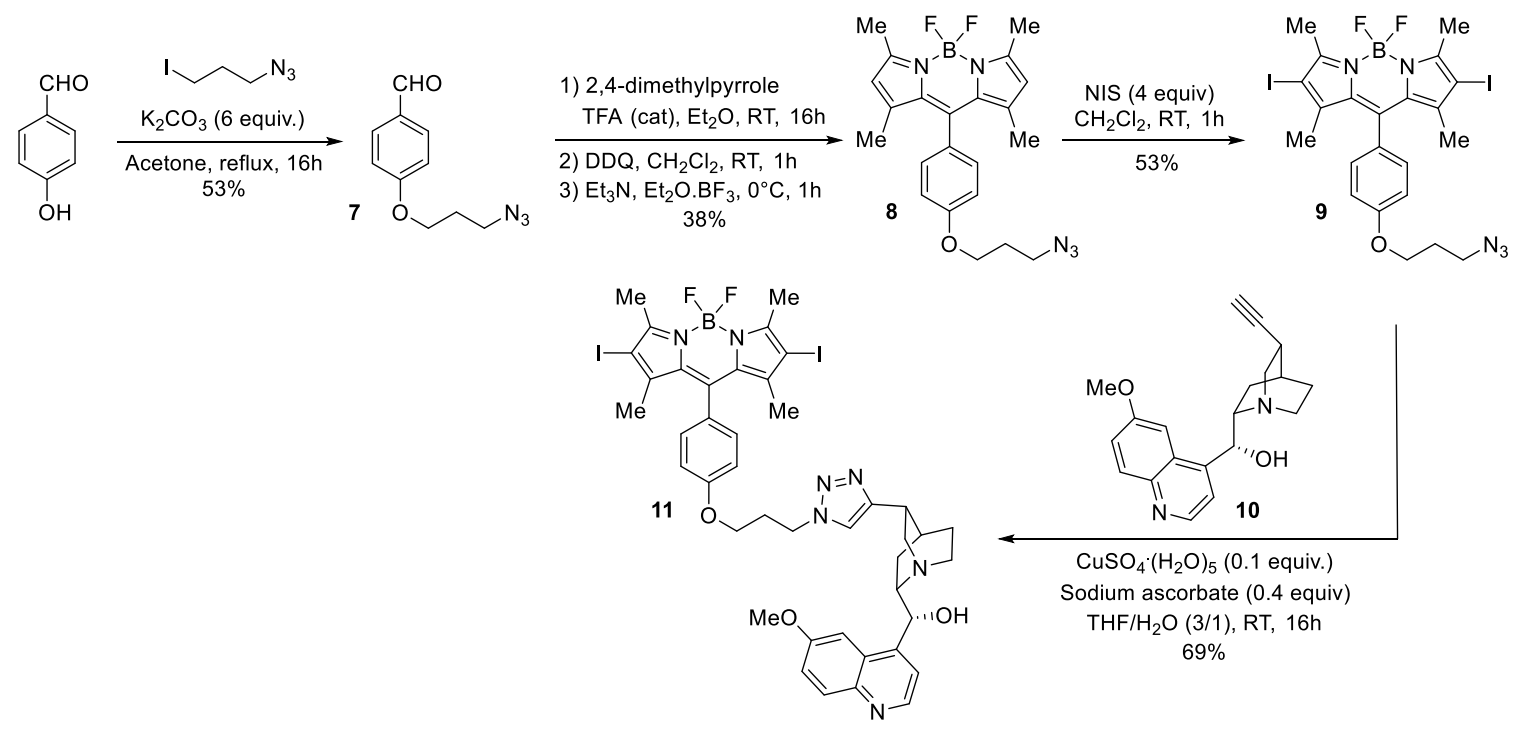

Scheme 2. Synthesis of the bifunctional photocatalyst 11 . 
The synthesis started by alkylation of 4-hydroxybenzaldehyde with 1-azido 3-iodopropane in the presence of potassium carbonate affording the aldehyde 7 in $53 \%$ yield. Starting from 7 and 2,4-dimethylpyrrole, the classical three-step sequence produced BODIPY 8 in $38 \%$ overall yield. Double iodination in the presence of $\mathrm{N}$-iodosuccinimide in dichloromethane led to the BODIPY 9 which underwent a copper-catalyzed Huisgen 1,3dipolar cycloaddition with 10,11-didehydroquinine 10. Under these conditions, the bifunctional photocatalyst $\mathbf{1 1}$ was isolated in $69 \%$ yield. The catalytic activity of $\mathbf{1 1}$ was then probed by performing the photooxygenation of $\mathbf{1}$ (Scheme 3).<smiles>CC(=O)C1C(=O)Cc2ccccc21</smiles>

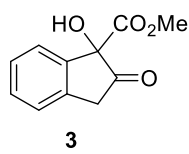

3
$\mathrm{T}=\mathrm{RT}$, yield $=75 \%$, ee $=40 \%$

$\mathrm{T}=0^{\circ} \mathrm{C}$, yield $=80 \%$, ee $=40 \%$

Scheme 3. Photooxygenation catalysed by 11 .

Irradiation from green LED in the presence of $5 \mathrm{~mol} \%$ of $\mathbf{1 1}$ at room temperature enabled the formation of $\mathbf{3}$ with slightly better enantiomeric excesses than reaction with $2 \mathrm{~mol} \%$ of 2 in conjunction with $5 \mathrm{~mol} \%$ of quinine. A better yield was obtained by running the reaction at $0^{\circ} \mathrm{C}$ while lowering the reaction temperature did not improve the enantiomeric excess. We next evaluated the substrate scope (Scheme 4).

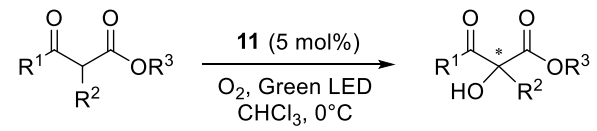

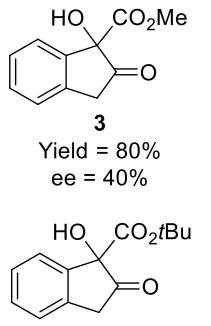

14

Yield $=58 \%$ ee $=0 \%$

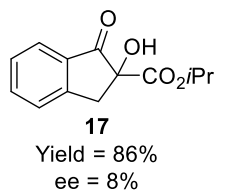<smiles>CC(=O)OC1(C(=O)O)C(=O)c2cccc3cccc1c23</smiles>

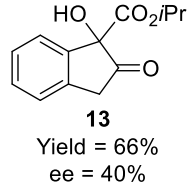

ee $=40 \%$<smiles>COC(=O)C1(O)Cc2ccccc2C1=O</smiles>$$
15
$$$$
\text { Yield }=37 \%
$$
Yield $=37 \%$
ee $=6 \%$<smiles>CCOC(=O)C1(O)Cc2ccccc2C1=O</smiles><smiles>COC(=O)CO</smiles><smiles>COC1(O)C(=O)CCc2ccccc21</smiles>
19 Yield $=18 \%$ ee $=2 \%$

$$
20
$$

We first evaluated different alkyl-2-oxo-1-indanecarboxylate under the optimized reaction conditions. Alcohols 12 and 13 were obtained in good yields and similar levels of enantioselection. Surprisingly, the product 14 was produced in $58 \%$ yield but in racemic form. Switching from alkyl 2-oxo-1-indanecarboxylate to alkyl 1-oxo-2-indanecarboxylate substrates had a negative impact on the enantioselectivities. Alcohols 15, 16 and 17 were obtained in moderate-to-excellent yields but with very low enantiomeric excesses. Nevertheless, the compound 18 was isolated in $73 \%$ yield and $36 \%$ ee. Compound $\mathbf{1 9}$ was obtained in a very low yield while the products $\mathbf{2 0}$ and $\mathbf{2 1}$ could not be obtained under green LED irradiation in the presence of $5 \mathrm{~mol} \%$ of $\mathbf{1 1}$ and the starting materials were recovered. Some mechanistic insights were considered by means of controlled experiments and kinetic analyses. We first investigated the ability of singlet oxygen quenching of the catalyst $\mathbf{1 1}$ by performing the photooxygenation of anthracene which is $\mathrm{a}^{1} \mathrm{O}_{2}$ chemical trap (Figure 2).
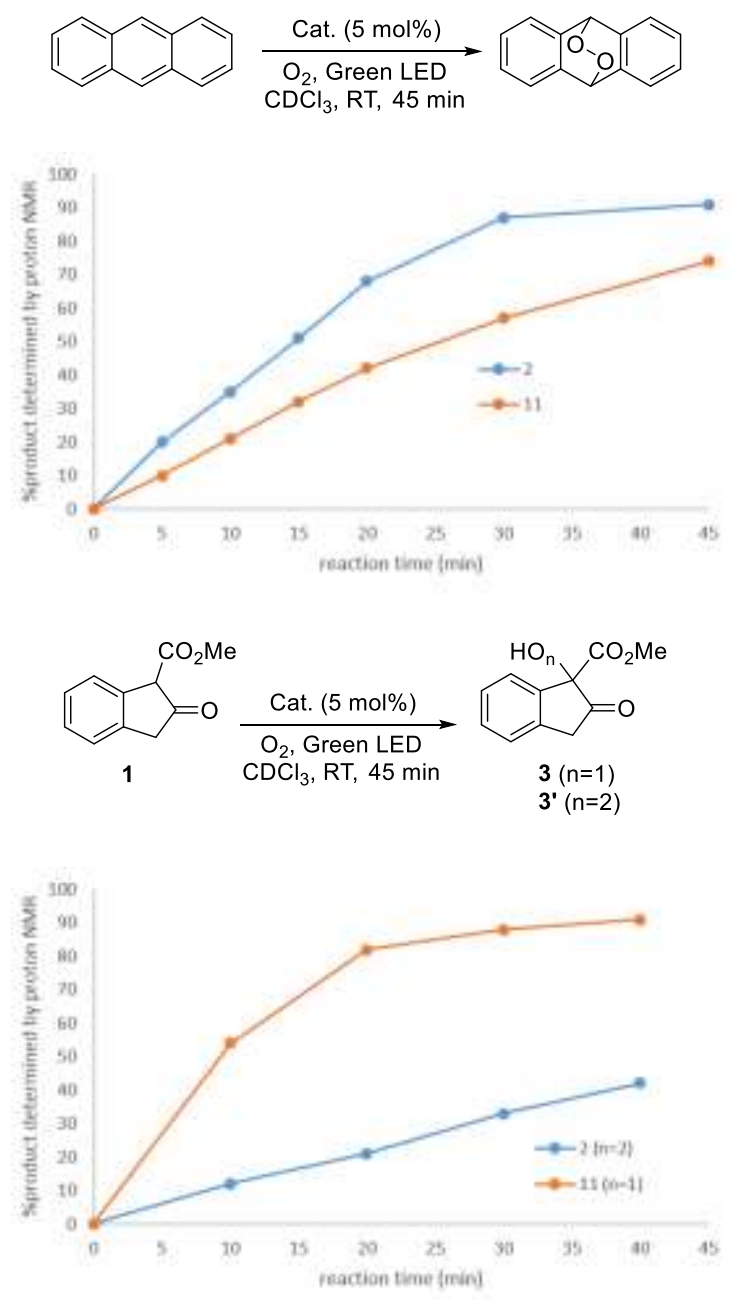

Figure 2. Photooxygenation kinetic profiles. 
Irradiation for $45 \mathrm{~min}$ in the presence of $5 \mathrm{~mol} \%$ of 11 led to $90 \%$ ${ }^{1} \mathrm{H}$ NMR yield of anthracene-9,10-endoperoxide while an increase of the kinetic activity was observed with iodo-BODIPY 2. Therefore, the quinine moiety would act as a singlet oxygen quencher in the photooxygenation of anthracene. The activation role of quinine in the photooxygenation of $\beta$-dicarbonyl compounds was investigated by monitoring the oxidation of 1 . A fast photooxygenation process was observed by running the reaction with $5 \mathrm{~mol} \%$ of $\mathbf{1 1}$. The kinetic was much slower when the iodo-BODIPY 2 was used highlighting the crucial role of quinine in activating the substrate $\mathbf{1}$ towards singlet oxygen. It is worthwhile noting that the hydroperoxide product 3' was obtained with iodo-BODIPY 2 and therefore, this is an intermediate in the photooxygenation reaction.

Control experiments have also been carried out to get a better understanding of the reaction mechanism (Scheme 5). First, photooxygenation of $\mathbf{1}$ was carried out in the presence of triphenylphosphine in order to in-situ reduce the hydroperoxide intermediate 3'. The results suggest that addition of singlet oxygen to 1 demonstrates low enantioselection. Secondly, the hydroperoxide 3' was prepared in-situ and quinine (5 mol\%) was added to the reaction mixture followed by the ethyl-derived substrate. This outcome suggests that the enantioselection would originate from the reaction of the hydroperoxide intermediate 3' with the substrate. ${ }^{[22]}$

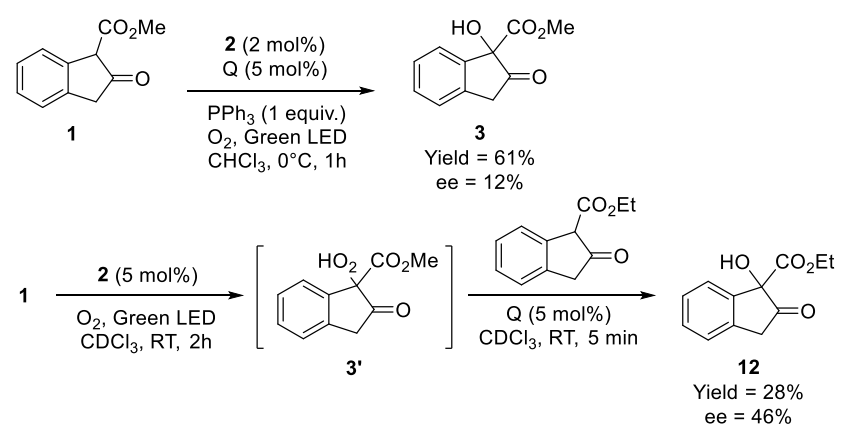

Scheme 5. Control experiments.

\section{Conclusions}

In summary, we prepared a new bifunctional photosensitizer composed of a iodo-BODIPY architecture connected to a quinine moiety which plays a dual role. In the absence of substrate, singlet oxygen would be physically quenched in order to prevent racemic background photooxygenation while interaction of the substrate with the aminocatalyst would trigger the photooxygenation. To this aim, the bifunctional photosensitizer has been applied to the photooxygenation of a focus selection of $\beta$-dicarbonyl compounds and the oxygenated products have been isolated with enantiomeric excesses of up to $40 \%$. Kinetic analyses and control experiments were carried out in order to get a better understanding of the mechanism.

\section{Experimental Section}

General remarks: ${ }^{1} \mathrm{H}$ NMR and ${ }^{13} \mathrm{C}$ spectra were recorded on a BRUKER AC300 (300 MHz for ${ }^{1} \mathrm{H}$ and $75 \mathrm{MHz}$ for ${ }^{13} \mathrm{C}$ ) at room temperature on samples dissolved in $\mathrm{CDCl}_{3}$. Chemical shifts $(\delta)$ are given in parts per million and coupling constants are given as absolute values expressed in Hertz. High-resolution mass spectrometry (HRMS) analyses were recorded on a XEVO G2-XS QTOF (Waters). Infrared spectra were recorded with a Bruker Tensor 27 FT ATR spectrometer. Melting points were determined on a Stuart melting point SMP3 apparatus. Thin-layer chromatography (TLC) was carried out on aluminium sheets precoated with silica gel $60 \mathrm{~F}_{254}$ (Merck). Column chromatography separations were performed using Merck Kieselgel 60 (0.040-0.060 mm). Chloroform was dried immediately before use by distillation from standard drying agents. The iodo-BODIPY photosensitizer 2, ${ }^{[21]}$ O-benzylquinine 4, ${ }^{[23]}$ 9-amino-9deoxyepiquinine $5,{ }^{[23]}$ 2-phenylquinine $6,{ }^{[24]}$ and 10,11 -didehydroquinine $\mathbf{1 0}^{[25]}$ were prepared according to literature procedures.

General procedure for the photooxygenation: To a Schlenk flask was added $\beta$-dicarbonyl compounds $(0.21 \mathrm{mmol})$ and photosensitizer 2 or 11 was added in $\mathrm{CHCl}_{3}(4.2 \mathrm{~mL})$. The reaction medium was gently bubbled with dioxygen throughout the reaction time and the homogeneous solution was irradiated with two green LEDs $(1 \mathrm{~W}, 75 \mathrm{Lm}, 535 \mathrm{~nm}$ typical wavelength). The distance from the light source to the irradiation Schlenk vessel was $2 \mathrm{~cm}$ without the use of any filters. The reaction was stirred for the appropriate reaction time at which point the solvent was removed under reduced pressure. The crude was purified by chromatography on silica gel to give the desired product.

Methyl 1-hydroxy-2-oxo-2,3-dihydro-1H-indene-1-carboxylate 3: The compound 3 was prepared according to the general procedure starting from methyl 2-oxoindane 1-carboxylate $(0.21 \mathrm{mmol}, 40 \mathrm{mg})$ and $11(10.5$ $\mu \mathrm{mol}, 10.5 \mathrm{mg}, 5 \mathrm{~mol} \%)$. The reaction mixture was stirred for $1 \mathrm{~h}$. Purification by column chromatography, eluting with $6: 4$ petroleum ether:diethylether, gave compound $\mathbf{3}$ as a solid (34.7 mg, 80\%). M.p. 138$140^{\circ} \mathrm{C} ; \delta_{\mathrm{H}}\left(300 \mathrm{MHz}, \mathrm{CDCl}_{3}\right) 7.45-7.32(4 \mathrm{H}, \mathrm{m}), 4.31(1 \mathrm{H}, \mathrm{s}), 3.86(1 \mathrm{H}, \mathrm{d}$, $J=22.0 \mathrm{~Hz}), 3.72(3 \mathrm{H}, \mathrm{s}), 3.62(1 \mathrm{H}, \mathrm{d}, J=22.0 \mathrm{~Hz}) ; \delta_{\mathrm{C}}\left(75 \mathrm{MHz}, \mathrm{CDCl}_{3}\right)$ 209.7, 170.7, 138.8, 137.4, 130.2, 128.3, 125.2, 124.4, 81.6, 53.8, 41.4. IR (ATR)/ $/ \mathrm{cm}^{-1} 3398$ (u, O-H), 1767 (u, C=O), 1739 (u, C=O); HRMS (ESI) Calcd for $\mathrm{C}_{11} \mathrm{H}_{10} \mathrm{O}_{4} \mathrm{Na}[\mathrm{M}+\mathrm{Na}]^{+}: 229.0477$ found: 229.0470 .

Ethyl 1-hydroxy-2-oxo-2,3-dihydro-1H-indene-1-carboxylate 12: The compound 12 was prepared according to the general procedure starting from ethyl 2-oxoindane 1-carboxylate $(0.21 \mathrm{mmol}, 42.9 \mathrm{mg})$ and $\mathbf{1 1}(10.5$ $\mu \mathrm{mol}, 10.5 \mathrm{mg}, 5 \mathrm{~mol} \%)$. The reaction mixture was stirred for $45 \mathrm{~min}$. Purification by column chromatography, eluting with $7: 3$ petroleum ether:diethylether, gave compound 12 as an oil $(29.1 \mathrm{mg}, 63 \%) . \delta_{\mathrm{H}}(300$ $\left.\mathrm{MHz}, \mathrm{CDCl}_{3}\right) 7.44-7.32(4 \mathrm{H}, \mathrm{m}), 4.31(1 \mathrm{H}, \mathrm{s}), 4.24(1 \mathrm{H}, \mathrm{dq}, J=10.7,7.2$ $\mathrm{Hz}), 4.13(1 \mathrm{H}, \mathrm{dq}, J=10.7,7.2 \mathrm{~Hz}), 3.84(1 \mathrm{H}, \mathrm{d}, J=21.8 \mathrm{~Hz}), 3.62(1 \mathrm{H}, \mathrm{d}$, $J=21.8 \mathrm{~Hz}), 1.15(3 \mathrm{H}, \mathrm{t}, J=7.2 \mathrm{~Hz}) ; \delta_{\mathrm{C}}\left(75 \mathrm{MHz}, \mathrm{CDCl}_{3}\right) 209.8,170.2$, $139.1,137.4,130,1,128.2,125.2,124.3,81.6,63.1,41.4,13.8$. IR (ATR)/cm ${ }^{-1} 3385(\mathrm{u}, \mathrm{O}-\mathrm{H}), 1766(\mathrm{u}, \mathrm{C}=\mathrm{O}), 1737(\mathrm{u}, \mathrm{C}=\mathrm{O})$; HRMS (ESI) Calcd for $\mathrm{C}_{12} \mathrm{H}_{12} \mathrm{O}_{4} \mathrm{Na}[\mathrm{M}+\mathrm{Na}]^{+}: 243.0633$ found: 243.0622 .

Isopropyl 1-hydroxy-2-oxo-2,3-dihydro-1H-indene-1-carboxylate 13: The compound 13 was prepared according to the general procedure starting from isopropyl 2-oxoindane 1-carboxylate $(0.21 \mathrm{mmol}, 45.8 \mathrm{mg})$ and 11 (10.5 $\mu \mathrm{mol}, 10.5 \mathrm{mg}, 5 \mathrm{~mol} \%)$. The reaction mixture was stirred for 4h. Purification by column chromatography, eluting with $7: 3$ petroleum ether:diethylether, gave compound 13 as an oil $(32.6 \mathrm{mg}, 66 \%) . \delta_{H}(300$ $\left.\mathrm{MHz}, \mathrm{CDCl}_{3}\right)$ 7.43-7.30 (4H, m), $5.02(1 \mathrm{H}$, sept, $J=6.3 \mathrm{~Hz}), 4.34(1 \mathrm{H}, \mathrm{s})$, $3.81(1 \mathrm{H}, \mathrm{d}, J=21.8 \mathrm{~Hz}), 3.60(1 \mathrm{H}, \mathrm{d}, J=21.8 \mathrm{~Hz}), 1.17(3 \mathrm{H}, \mathrm{d}, J=6.3$ $\mathrm{Hz}), 1.06(3 \mathrm{H}, \mathrm{d}, J=6.3 \mathrm{~Hz})$; $\delta_{\mathrm{C}}\left(75 \mathrm{MHz}, \mathrm{CDCl}_{3}\right) 209.9,169.8,139.2$, 
137.4, 129.9, 128.2, 125.1, 124.1, 81.7, 71.3, 41.5, 21.3 (2C). IR (ATR)/cm $\mathrm{cm}^{-1} 3422(\mathrm{u}, \mathrm{O}-\mathrm{H}), 1768$ (u, C=O), 1729 (u, C=O). HRMS (ESI) Calcd for $\mathrm{C}_{13} \mathrm{H}_{14} \mathrm{O}_{4} \mathrm{Na}[\mathrm{M}+\mathrm{Na}]^{+}: 257.0790$ found: 257.0784 .

Tertbutyl 1-hydroxy-2-oxo-2,3-dihydro-1H-indene-1-carboxylate 14: The compound 14 was prepared according to the general procedure starting from tertbutyl 2-oxoindane 1-carboxylate $(0.21 \mathrm{mmol}, 48.8 \mathrm{mg})$ and $11(10.5 \mu \mathrm{mol}, 10.5 \mathrm{mg}, 5 \mathrm{~mol} \%)$. The reaction mixture was stirred for 4h. Purification by column chromatography, eluting with $7: 3$ petroleum ether:diethylether, gave compound $\mathbf{1 4}$ as a solid $(30.2 \mathrm{mg}, 58 \%)$. M.p. 93 $95^{\circ} \mathrm{C} ; \delta_{\mathrm{H}}\left(300 \mathrm{MHz}, \mathrm{CDCl}_{3}\right) 7.42-7.30(4 \mathrm{H}, \mathrm{m}), 4.29(1 \mathrm{H}, \mathrm{bs}), 3.78(1 \mathrm{H}, \mathrm{d}$, $J=21.7 \mathrm{~Hz}), 3.58(1 \mathrm{H}, \mathrm{d}, J=21.7 \mathrm{~Hz}), 1.34(9 \mathrm{H}, \mathrm{s}) ; \delta_{\mathrm{C}}\left(75 \mathrm{MHz}, \mathrm{CDCl}_{3}\right)$ 210.4, 169.4, 139.8, 137.4, 129.9, 128.2, 125.2, 124.0, 84.7, 82.0, 41.7, 27.7 (3C). IR (ATR)/ $/ \mathrm{cm}^{-1} 3408(\mathrm{u}, \mathrm{O}-\mathrm{H}), 1764(\mathrm{u}, \mathrm{C}=\mathrm{O}), 1735(\mathrm{u}, \mathrm{C}=\mathrm{O})$ HRMS (ESI) Calcd for $\mathrm{C}_{14} \mathrm{H}_{16} \mathrm{O}_{4} \mathrm{Na}[\mathrm{M}+\mathrm{Na}]^{+}: 271.0946$ found: 271.0938.

\begin{abstract}
Methyl 2-hydroxy-1-oxo-2,3-dihydro-1H-indene-2-carboxylate 15: The compound 15 was prepared according to the general procedure starting from methyl 1-oxoindane 2-carboxylate $(0.21 \mathrm{mmol}, 40 \mathrm{mg})$ and $11(10.5$ $\mu \mathrm{mol}, 10.5 \mathrm{mg}, 5 \mathrm{~mol} \%)$. The reaction mixture was stirred for $3 \mathrm{~h}$. Purification by column chromatography, eluting with $7: 3$ petroleum ether:diethylether, gave compound 15 as a solid $(16.1 \mathrm{mg}, 37 \%) . \delta_{\mathrm{H}}(300$ $\left.\mathrm{MHz}, \mathrm{CDCl}_{3}\right) 7.80(1 \mathrm{H}, \mathrm{dd}, J=7.7,0.7 \mathrm{~Hz}), 7.67(1 \mathrm{H}, \mathrm{td}, J=7.3,1.4 \mathrm{~Hz})$ $7.49(1 \mathrm{H}, \mathrm{dt}, J=7.7,1.4 \mathrm{~Hz}), 7.43(1 \mathrm{H}, \mathrm{td}, J=7.3,0.7 \mathrm{~Hz}), 4.02(1 \mathrm{H}, \mathrm{s})$ $3.73(3 \mathrm{H}, \mathrm{s}), 3,73(1 \mathrm{H}, \mathrm{d}, J=17.3 \mathrm{~Hz}), 3.25(1 \mathrm{H}, \mathrm{d}, J=17.3 \mathrm{~Hz})$. The analytical data are in complete agreement with the previously published data. ${ }^{[26]}$
\end{abstract}

Ethyl 2-hydroxy-1-oxo-2,3-dihydro-1H-indene-2-carboxylate 16: The compound 16 was prepared according to the general procedure starting from ethyl 1-oxoindane 2-carboxylate $(0.21 \mathrm{mmol}, 42.9 \mathrm{mg})$ and 11 (10.5 umol, $10.5 \mathrm{mg}, 5 \mathrm{~mol} \%)$. The reaction mixture was stirred for $3 \mathrm{~h}$. Purification by column chromatography, eluting with $7: 3$ petroleum ether:diethylether, gave compound 16 as a solid $(27.2 \mathrm{mg}, 59 \%)$. $\delta_{H}(300$ $\left.\mathrm{MHz}, \mathrm{CDCl}_{3}\right) 7.79(1 \mathrm{H}, \mathrm{dd}, J=7.7,0.8 \mathrm{~Hz}), 7.66(1 \mathrm{H}, \mathrm{td}, J=7.4,0.8 \mathrm{~Hz})$ $7.49(1 \mathrm{H}, \mathrm{dt}, J=7.7,0.8 \mathrm{~Hz}), 7.42(1 \mathrm{H}, \mathrm{td}, J=7.4,0.8 \mathrm{~Hz}), 4.16(1 \mathrm{H}, \mathrm{dd}$, $J=7.1,2.3 \mathrm{~Hz}), 4.12(1 \mathrm{H}, \mathrm{dd}, J=7.1,2.3 \mathrm{~Hz}), 4.02(1 \mathrm{H}, \mathrm{s}), 3.72(1 \mathrm{H}, \mathrm{d}, J$ $=17.3 \mathrm{~Hz}), 3.24(1 \mathrm{H}, \mathrm{d}, J=17.3 \mathrm{~Hz}), 1.17(3 \mathrm{H}, \mathrm{t}, J=7.1 \mathrm{~Hz})$. The analytical data are in complete agreement with the previously published data. ${ }^{[26]}$

Isopropyl 2-hydroxy-1-oxo-2,3-dihydro-1H-indene-2-carboxylate 17: The compound $\mathbf{1 7}$ was prepared according to the general procedure starting from isopropyl 1-oxoindane 2-carboxylate $(0.21 \mathrm{mmol}, 45.8 \mathrm{mg})$ and $11(10.5 \mu \mathrm{mol}, 10.5 \mathrm{mg}, 5 \mathrm{~mol} \%)$. The reaction mixture was stirred for 4h. Purification by column chromatography, eluting with $7: 3$ petroleum ether:diethylether, gave compound 17 as a solid $(42.3 \mathrm{mg}, 86 \%)$. $\delta_{\mathrm{H}}(300$ $\left.\mathrm{MHz}, \mathrm{CDCl}_{3}\right) 7.77(1 \mathrm{H}, \mathrm{dd}, J=7.7,0.8 \mathrm{~Hz}), 7.64(1 \mathrm{H}, \mathrm{td}, J=7.3,0.8 \mathrm{~Hz})$, $7.47(1 \mathrm{H}, \mathrm{dt}, J=7.7,0.8 \mathrm{~Hz}), 7.40(1 \mathrm{H}, \mathrm{td}, J=7.3,0.8 \mathrm{~Hz}), 5.05(1 \mathrm{H}$, sept $J=6.3 \mathrm{~Hz}), 4.07(1 \mathrm{H}, \mathrm{s}), 3.68(1 \mathrm{H}, \mathrm{d}, J=17.3 \mathrm{~Hz}), 3.22(1 \mathrm{H}, \mathrm{d}, J=17.3$ $\mathrm{Hz}), 1.17(3 \mathrm{H}, \mathrm{d}, J=6.3 \mathrm{~Hz}), 1.10(3 \mathrm{H}, \mathrm{d}, J=6.3 \mathrm{~Hz})$. The analytical data are in complete agreement with the previously published data. ${ }^{[26]}$

Methyl 1-hydroxy-2-oxo-1,2-dihydroacenaphthylene-1-carboxylate 18: The compound 18 was prepared according to the general procedure starting from methyl 2-oxo-1,2-dihydroacenaphthylene-1-carboxylate $(0.21 \mathrm{mmol}, 47.5 \mathrm{mg})$ and $11(10.5 \mu \mathrm{mol}, 10.5 \mathrm{mg}, 5 \mathrm{~mol} \%)$. The reaction mixture was stirred for $1 \mathrm{~h}$. Purification by column chromatography, eluting with 7:3 petroleum ether:diethylether, gave compound $\mathbf{1 8}$ as a solid (37.1 mg, $73 \%$ ). M.p. $163-165^{\circ} \mathrm{C} ; \delta_{\mathrm{H}}\left(300 \mathrm{MHz}, \mathrm{CDCl}_{3}\right) 8.17(1 \mathrm{H}, \mathrm{d}, J=8.1 \mathrm{~Hz})$, $8.04(1 \mathrm{H}, \mathrm{d}, J=7.0 \mathrm{~Hz}), 7.97(1 \mathrm{H}, \mathrm{d}, J=8.3 \mathrm{~Hz}), 7.78(1 \mathrm{H}, \mathrm{dd}, J=8.1,7.0$ $\mathrm{Hz}), 7.79(1 \mathrm{H}, \mathrm{dd}, J=8.3,7.0 \mathrm{~Hz}), 7.71(1 \mathrm{H}, \mathrm{d}, J=7.0 \mathrm{~Hz}), 4.50(1 \mathrm{H}, \mathrm{bs})$, $3.66(3 \mathrm{H}, \mathrm{s}) ; \delta_{\mathrm{C}}\left(75 \mathrm{MHz}, \mathrm{CDCl}_{3}\right)$ 199.0, 171.3, 143.4, 136.3, 132.3, 131.2, 131.0, 128.9, 128.6, 126.5, 123.2, 120.8, 81.3, 53.8. IR (ATR) $/ \mathrm{cm}^{-1} 3447$ (u, O-H), $1718(\mathrm{u}, \mathrm{C}=\mathrm{O})$. HRMS (ESI) Calcd for $\mathrm{C}_{14} \mathrm{H}_{10} \mathrm{O}_{4} \mathrm{Na}[\mathrm{M}+\mathrm{Na}]^{+}$: 265.0477 found: 265.0469

Methyl 1-hydroxy-2-oxo-1,2,3,4-tetrahydronaphthalene-1-carboxylate 19: The compound 18 was prepared according to the general procedure starting from methyl 2-oxo-1,2,3,4-tetrahydronaphthalene-1-carboxylate ( $0.21 \mathrm{mmol}, 46.2 \mathrm{mg}, 1.00$ equiv.) and $\mathbf{1 1}(10.5 \mu \mathrm{mol}, 10.5 \mathrm{mg}, 5 \mathrm{~mol} \%)$ in $\mathrm{CHCl}_{3}(4.2 \mathrm{~mL})$. The reaction mixture was stiired for $4 \mathrm{~h}$. Purification by column chromatography, eluting with 7:3 petroleum ether:diethylether, gave compound 19 as a solid $(8.5 \mathrm{mg}, 18 \%)$. M.p. $95-98^{\circ} \mathrm{C} ; \delta_{\mathrm{H}}(300 \mathrm{MHz}$, $\left.\mathrm{CDCl}_{3}\right) 7.64(1 \mathrm{H}, \mathrm{m}), 7.33(2 \mathrm{H}, \mathrm{m}), 7.22(1 \mathrm{H}, \mathrm{m}), 4.56(1 \mathrm{H}, \mathrm{s}), 3.72(3 \mathrm{H}, \mathrm{s})$ $3.35(1 \mathrm{H}, \mathrm{m}), 3.07(2 \mathrm{H}, \mathrm{m}), 2.68(1 \mathrm{H}, \mathrm{m}) ; \delta_{\mathrm{C}}\left(75 \mathrm{MHz}, \mathrm{CDCl}_{3}\right) 206.9,169.9$, 136.1, 134.7, 129.0, 128.1, 127.6, 126.6, 79.8, 53.5, 34.6, 27.6. IR (ATR)/cm $\mathrm{cm}^{-1} 3424(\mathrm{u}, \mathrm{O}-\mathrm{H}), 1741(\mathrm{u}, \mathrm{C}=\mathrm{O}), 1709(\mathrm{u}, \mathrm{C}=\mathrm{O})$. HRMS (ESI) Calcd for $\mathrm{C}_{12} \mathrm{H}_{12} \mathrm{O}_{4} \mathrm{Na}[\mathrm{M}+\mathrm{Na}]^{+}: 243.0633$ found: 243.0629 .

4-(3-Azidopropoxy) benzaldehyde 7: 4-hydroxybenzaldehyde (11.4 mmol, $1.39 \mathrm{~g}, 1.20$ equiv.), azido-3-iodopropane $(9.48 \mathrm{mmol}, 2.00 \mathrm{~g}, 1.00$ equiv.) and potassium carbonate $(56.88 \mathrm{mmol}, 7.86 \mathrm{~g}, 6.00$ equiv.) were dissolved in acetone $(40 \mathrm{~mL})$ under argon and heated to reflux during $16 \mathrm{~h}$. The reaction mixture was then filtered, concentrated in vacuo, diluted in dichloromethane $(30 \mathrm{~mL})$. The solution was then washed with water $(3 x$ $20 \mathrm{~mL}$ ), dried with $\mathrm{Na}_{2} \mathrm{SO}_{4}$, filtered and concentrated in vacuo. Purification by column chromatography, eluting with $75: 25$ petroleum ether:ethyl acetate, gave 4-(3-azidopropoxy) benzaldehyde 7 as a light yellow liquid $(1.04 \mathrm{~g}, 53 \%) . \delta_{\mathrm{H}}\left(300 \mathrm{MHz}, \mathrm{CDCl}_{3}\right) 9.89(1 \mathrm{H}, \mathrm{s}), 7.87-7.82(2 \mathrm{H}, \mathrm{m}), 7.03$ $6.98(2 \mathrm{H}, \mathrm{m}), 4.13(2 \mathrm{H}, \mathrm{t}, J=6.0 \mathrm{~Hz}), 3.53(2 \mathrm{H}, \mathrm{t}, J=6.5 \mathrm{~Hz}), 2.13-2.04$ $(2 \mathrm{H}, \mathrm{m})$; The analytical data are in complete agreement with the previously published data. Further analysis matched with the literature. ${ }^{[27]}$

4,4-Difluoro-8-(4-(3-azidopropoxy))phenyl-1,3,5,7-tetramethyl-4-bora3a,4a-diaza-s-indacene 8: Compound 7 ( $4.87 \mathrm{mmol}, 1.00 \mathrm{~g}, 1.00$ equiv.), 2,4-dimethylpyrrole $(9.75 \mathrm{mmol}, 926 \mathrm{mg}, 2.00$ equiv.) and trifluoroacetic acid $(0.1 \mathrm{~mL})$ in diethylether $(235 \mathrm{~mL})$ were stirred under Argon at room temperature during 16h. 2,3-Dichloro-5,6-dicyano-1,4-benzoquinone (4.87 $\mathrm{mmol}, 1.105 \mathrm{~g}, 1.00$ equiv.) in dichloromethane $(32 \mathrm{~mL})$ was then added and allowed to stir for $1 \mathrm{~h}$ at room temperature. The reaction mixture was cooled at $0^{\circ} \mathrm{C}$, triethylamine $(19.5 \mathrm{~mL})$ then boron trifluoride ethyl etherate $(19.5 \mathrm{~mL})$ were added and allowed to stir for $1 \mathrm{~h}$ at $0^{\circ} \mathrm{C}$. The organic layer was then washed with water $(4 \times 200 \mathrm{~mL})$, dried with $\mathrm{Na}_{2} \mathrm{SO}_{4}$ and concentrated in vacuo. Purification by column chromatography, eluting with 1:1 dichloromethane:petroleum ether, gave compound 8 as an orange solid $(786 \mathrm{mg}, 38 \%)$. $\delta_{\mathrm{H}}\left(300 \mathrm{MHz}, \mathrm{CDCl}_{3}\right) 7.19-7.14(2 \mathrm{H}, \mathrm{m}), 7.02-6.98$ $(2 \mathrm{H}, \mathrm{m}), 5.96(2 \mathrm{H}, \mathrm{s}), 4.09(2 \mathrm{H}, \mathrm{t}, J=6.0 \mathrm{~Hz}), 3.55(2 \mathrm{H}, \mathrm{t}, J=6.6 \mathrm{~Hz}), 2.54$ $(6 \mathrm{H}, \mathrm{s}), 2.09(2 \mathrm{H}$, app. quint., $J=6.3 \mathrm{~Hz}), 1.42(6 \mathrm{H}, \mathrm{s})$. The analytical data are in complete agreement with the previously published data. ${ }^{[28]}$

\section{4,4-Difluoro-8-(4-(3-azidopropoxy))phenyl-2,6-diodo-1,3,5,7-}

tetramethyl-4-bora-3a,4a-diaza-s-indacene 9: Compound 8 (0.945 $\mathrm{mmol}, 400 \mathrm{mg}, 1.00$ equiv.) was dissolved in dichloromethane $(38 \mathrm{~mL})$ in a round-bottom flask under argon. $\mathrm{N}$-lodosuccinimide $(3.78 \mathrm{mmol}, 851 \mathrm{mg}$, 4 equiv.) was added and the reaction mixture was stirred at room temperature for $1 \mathrm{~h}$. The product was concentrated in vacuo. Purification by column chromatography, eluting with $7: 3$ petroleum ether:dichloromethane, gave compound 9 as a red solid (340 mg, 53\%). $\delta_{\mathrm{H}}\left(300 \mathrm{MHz}, \mathrm{CDCl}_{3}\right) 7.14(2 \mathrm{H}, \mathrm{d}, J=8.8 \mathrm{~Hz}), 7.03(2 \mathrm{H}, \mathrm{d}, J=8.8 \mathrm{~Hz})$, $4.13(2 \mathrm{H}, \mathrm{t}, J=6.0 \mathrm{~Hz}), 3.57(2 \mathrm{H}, \mathrm{t}, J=6.0 \mathrm{~Hz}), 2.64(6 \mathrm{H}, \mathrm{s}), 2.12(2 \mathrm{H}$, quint, $J=6.0 \mathrm{~Hz}), 1.44(6 \mathrm{H}, \mathrm{s}) ; \delta_{\mathrm{C}}\left(75 \mathrm{MHz}, \mathrm{CDCl}_{3}\right) 159.8,156.7(2 \mathrm{C})$, 145.5 (2C), 141.6, $131.8(2 \mathrm{C}), 129.3(2 \mathrm{C}), 127.1,115.5$ (2C), $85.7(2 \mathrm{C})$, 64.8, 48.3, 28.9, 17.3 (2C), 16.1 (2C). HRMS (ESI) Calcd for $\mathrm{C}_{22} \mathrm{H}_{21} \mathrm{~N}_{5} \mathrm{OF}_{2} \mathrm{l}_{2} \mathrm{~B}[\mathrm{M}-\mathrm{H}]: 672.9933$ found: 972.9918 .

Photosensitizer 11: In a schlenk tube were added compound 9 (0.296 mmol, $200 \mathrm{mg}, 1.00$ equiv.), 10 ( $0.444 \mathrm{mmol}, 143 \mathrm{mg}, 1.50$ equiv.) in a 1:3 
$\mathrm{H}_{2} \mathrm{O}$ :THF mixture. Sodium ascorbate $(0.119 \mathrm{mmol}, 23.5 \mathrm{mg}, 0.40$ equiv. and then copper sulfate pentahydrate $(0.030 \mathrm{mmol}, 7.4 \mathrm{mg}, 0.10$ equiv.) were added and stirred at room temperature for $16 \mathrm{~h}$. The solution was then concentrated in vacuo and dissolved in dichloromethane $(40 \mathrm{~mL})$. The organic layer was washed with a low concentration $\mathrm{NaCl}$ solution $(3 \times 20$ $\mathrm{mL}$ ) and dried with $\mathrm{Na}_{2} \mathrm{SO}_{4}$. The product was evaporated in vacuo. Purification by column chromatography, eluting with a 9:1 to $7: 3$ ethyl acetate:methanol gradiant, gave photosensitizer 11 as a red solid $(204 \mathrm{mg}$, $69 \%$ ). M.p. $178-181^{\circ} \mathrm{C} ; \delta_{\mathrm{H}}\left(300 \mathrm{MHz}, \mathrm{CDCl}_{3}\right) 8.68(1 \mathrm{H}, \mathrm{d}, J=4.5 \mathrm{~Hz}), 7.86$ $(1 \mathrm{H}, \mathrm{d}, J=9.2 \mathrm{~Hz}), 7.55(1 \mathrm{H}, \mathrm{d}, J=4.5 \mathrm{~Hz}), 7.21(\mathrm{~s}, 1 \mathrm{H}), 7.19(1 \mathrm{H}, \mathrm{dd}, J$ $=9.2,2.6 \mathrm{~Hz}), 7.12-7.10(3 \mathrm{H}, \mathrm{m}), 6.91(2 \mathrm{H}, \mathrm{d}, J=8.7 \mathrm{~Hz}), 6.01(1 \mathrm{H}, \mathrm{br} . \mathrm{S})$, $4.46(2 \mathrm{H}, \mathrm{t}, J=6.9 \mathrm{~Hz}), 4.17-4.03(1 \mathrm{H}, \mathrm{m}), 4.00-3.97(1 \mathrm{H}, \mathrm{m}), 3.89-3.78$ $(\mathrm{m}, 1 \mathrm{H}), 3.82(3 \mathrm{H}, \mathrm{s}), 3.71-3.63(1 \mathrm{H}, \mathrm{m}), 3.59-3.42(2 \mathrm{H}, \mathrm{m}), 3.28-3.20(1 \mathrm{H}$, $\mathrm{m}), 3.06-2.95(1 \mathrm{H}, \mathrm{m}), 2.64(6 \mathrm{H}, \mathrm{s}), 2.34-2.25(2 \mathrm{H}, \mathrm{m}), 2.20-2.05(2 \mathrm{H}, \mathrm{m})$, 1.97-1.78 (2H, m), $1.40(6 \mathrm{H}, \mathrm{s}), 1.30-1.18(2 \mathrm{H}, \mathrm{m}) ; \delta_{\mathrm{C}}\left(75 \mathrm{MHz}, \mathrm{CDCl}_{3}\right)$ $159.5,158.2,156.9$ (2C), 148.7, 147.5, 145.7, 145.3, 144.2, 141.3, 131.8 (2C), 131.6, 129.4 (2C), 127.5, 126.1, 125.8, 122.1, 121.1, 118.8, 115.4 (2C), 100.7, 85.8 (2C), 64.4, 59.8, 56.3, 55.0, 47.2, 43.8, 32.5, 29.9, 28.0, 25.8, 20.2, $17.3(2 \mathrm{C}), 16.2(2 \mathrm{C})$. IR (ATR)/cm $\mathrm{cm}^{-1} 3232(\mathrm{u}, \mathrm{O}-\mathrm{H}), 2930$ (u, CH), 1526 (u, C-H), 1175 (u, C-O), 993 (u, C=C), 525 (u, C-I); HRMS (ESI) Calcd for $\mathrm{C}_{42} \mathrm{H}_{43} \mathrm{~N}_{7} \mathrm{O}_{3} \mathrm{~F}_{2} \mathrm{l}_{2} \mathrm{~B}[\mathrm{M}-\mathrm{H}]-995.1614$ found: 995.1578 .

\section{Acknowledgments}

This work was supported by The Région Pays de la Loire (NANO2 project) which financed a PhD grant for JF. We also thank University of Nantes and CNRS for financial support.

\section{Keywords: Singlet oxygen $•$ Photooxidation $•$ Asymmetric} catalysis $\bullet$ Energy transfer $\bullet \beta$-dicarbonyl compounds

[1] For selected reviews, see: a) T. P.Nicholls, D. Leonori, A. C. Bissember, Nat. Prod. Rep. 2016, 33, 1248-1254; b) K. L. Skubi, T. R. Blum, T. P. Yoon, Chem. Rev. 2016, 116, 10035-10074; c) M. D. Kärkäs, J. A. Porco, C. R. J. Stephenson, Chem. Rev. 2016, 116, 9683-9747; d) M. H. Shaw, J. Twilton, D. W. C. MacMillan, J. Org. Chem. 2016, 81, 6898-6926; e) T. Bach, J. P. Hehn, Angew. Chem. Int. Ed. 2011, 50, 1000-1045.

[2] a) E. M. Sherbrook, T. P. Yoon. Asymmetric Catalysis of Triplet State Photoreactions. In Specialist Periodical Reports: Photochemistry (Eds: A Albini, S. Protti); Royal Society of Chemistry: Croydon, 2019; b) Y.-Q. Zou, F. M. Hörmann, T. Bach, Chem. Soc. Rev. 2018, 47, 278-290; c) R Brimioulle, D. Lenhart, M. M. Maturi, T. Bach, Angew. Chem. Int. Ed. 2015, 54, 3872-3890; d) E. Meggers, Chem. Commun. 2015, 51, 32903301.

[3] a) Q.-Q. Zhou, Y.-Q. Zou, L.-Q. Lu, W.-J. Xiao, Angew. Chem. Int. Ed. 2019, 58, 1586-1604; b) F. Strieth-Kalthoff, M. J. James, M. Teders, L. Pitzer, F. Glorius, Chem. Soc. Rev. 2018, 47, 7190-7202.

[4] For recent examples of asymmetric [2+2] photocycloadditions, see: a) M. E. Daub, H. Jung, B. J. Lee, J. Won, M.-H. Baik, T. P. Yoon, J. Am. Chem. Soc. 2019, DOI 10.1021/jacs.9b04643; b) F. M. Hörmann, T. S. Chung, E. Rodriguez, M. Jakob, T. Bach, Angew. Chem. Int. Ed. 2018, 57, 827831 ; c) S. Poplata, T. Bach, J. Am. Chem. Soc. 2018, 140, 3228-3231; d) K. L. Skubi, J. B. Kidd, H. Jung, I. A. Guzei, M.-H. Baik, T. P. Yoon, J. Am. Chem. Soc. 2017, 139, 17186-17192; e) Z. D. Miller, B. J. Lee, T. P. Yoon, Angew. Chem. Int. Ed. 2017, 56, 11891-11895; f) X. Huang, T. R. Quinn, K. Harms, R. D. Webster, L. Zhang, O. Wiest, E. Meggers, J. Am. Chem. Soc. 2017, 139, 9120-9123; g) A. Tröster, R. Alonso, A. Bauer, T. Bach, J. Am. Chem. Soc. 2016, 138, 7808-7811; h) F. Mayr, R. Brimioulle T. Bach, J. Org. Chem. 2016, 81, 6965-6971; i) N. Vallavoju, S. Selvakumar, S. Jockusch, M. P. Sibi, J. Sivaguru, Angew. Chem. Int. Ed. 2014, 53, 5604-5608; j) R. Alonso, T. Bach, Angew. Chem. Int. Ed. 2014
53, 4368-4371; k) H. Huo, X. Shen, C. Wang, L. Zhang, P. Röse, L.-A. Chen, K. Harms, M. Marsch, G. Hilt, E. Meggers, Nature 2014, 515, 100 103; I) R. Brimioulle, T. Bach, Angew. Chem. Int. Ed. 2014, 53, 1292112924.

[5] a) I. Pibiri, S. Buscemi, A. Palumbo Piccionello, A. Pace ChemPhotoChem 2018, 2, 535-547; b) S. Nonell, C. Flors, Eds. , Singlet Oxygen: Applications in Biosciences and Nanosciences, The Royal Society Of Chemistry, 2016.

[6] For selected reviews about heteroatom oxidation, see: a) N. Sawwan, A Greer, Chem. Rev. 2007, 107, 3247-3285; b) E. L. Clennan, Acc. Chem. Res. 2001, 34, 875-884.

[7] M. R. lesce, F. Cermola, in Handbook of Organic Photochemistry and Photobiology, 3rd ed., (eds: A. Griesbeck, M. Oelgemöller, F. Ghetti), CRC Press: Boca Raton, FL, 2012, 727-764.

[8] For selected reviews about Schenck-ene reactions: a) P. Bayer, R Pérez-Ruiz, A. Jacobi von Wangelin, ChemPhotoChem 2018, 2, 559570; b) M. N. Alberti, M. Orfanopoulos, Chem. Eur. J. 2010, 16, 9414 9421; c) M. N. Alberti, M. Orfanopoulos, Synlett 2010, 999-1026; d) A. Greer, Acc. Chem. Res. 2006, 39, 797-804; e) E. L. Clennan, Tetrahedron 2000, 56, 9151-9179.

[9] For selected recent examples, see: a) L. Péault, P. Nun, E. Le Grognec, V. Coeffard, Chem. Commun. 2019, 55, 7398-7401; b) H. Umihara, T. Yoshino, J. Shimokawa, M. Kitamura, T. Fukuyama, Angew. Chem. Int. Ed. 2016, 55, 6915-6918; c) G. Tong, Z. Liu, P. Li, Org. Lett. 2014, 16, 2288-2291; d) K. M. Jones, T. Hillringhaus, M. Klussmann, Tetrahedron Lett. 2013, 54, 3294-3297; e) T. R. Hoye, C. S. Jeffrey, D. P. Nelson, Org Lett. 2010, 12, 52-55.

[10] For selected recent examples, see: a) L. Marin, G. Force, R. Guillot, V. Gandon, E. Schulz, D. Lebœuf, Chem. Commun. 2019, 55, 5443-5446; b) G. I. Ioannou, T. Montagnon, D. Kalaitzakis, S. A. Pergantis, G. Vassilikogiannakis, ChemPhotoChem 2018, 2, 860-864; c) M. Triantafyllakis, K. Sfakianaki, D. Kalaitzakis, G. Vassilikogiannakis, Org. Lett. 2018, 20, 3631-3634; d) D. Kalaitzakis, M. Triantafyllakis, G. I. Ioannou, G. Vassilikogiannakis, Angew. Chem. Int. Ed. 2017, 56, 40204023; e) T. Montagnon, D. Kalaitzakis, M. Sofiadis, G. Vassilikogiannakis, Org. Biomol. Chem. 2016, 14, 8636-8640.

[11] A. A. Ghogare, A. Greer, Chem. Rev. 2016, 116, 9994-10034.

[12] a) L. Weber, I. Imiolczyk, G. Haufe, D. Rehorek, H. Hennig, J. Chem. Soc. Chem. Commun. 1992, 301-303; b) Y. Kuroda, T. Sera, H. Ogoshi, J. Am. Chem. Soc. 1991, 113, 2793-2794.

[13] D. J. Walaszek, K. Rybicka-Jasińska, S. Smoleń, M. Karczewski, D. Gryko, Adv. Synth. Catal. 2015, 357, 2061-2070.

[14] M. Lian, Z. Li, Y. Cai, Q. Meng, Z. Gao, Chem. Asian J. 2012, 7, 2019 2023.

[15] a) Y. Wang, Z. Zheng, M. Lian, H. Yin, J. Zhao, Q. Meng, Z. Gao, Green Chem. 2016, 18, 5493-5499; b) Y. Wang, H. Yin, X. Tang, Y. Wu, Q. Meng, Z. Gao, J. Org. Chem. 2016, 81, 7042-7050.

[16] W. Ding, L.-Q. Lu, Q.-Q. Zhou, Y. Wei, J.-R. Chen, W.-J. Xiao, J. Am Chem. Soc. 2017, 139, 63-66.

[17] a) A. G. Griesbeck, M. A. Miranda, J. Uhlig, Photochem. Photobiol. Sci. 2011, 10, 1431-1435; b) A. Joy, R. J. Robbins, K. Pitchumani, V. Ramamurthy, Tetrahedron Lett. 1997, 38, 8825-8828.

[18] S. Callaghan, M. O. Senge, Photochem. Photobiol. Sci. 2018, 17, 14901514.

[19] E. Lemp, G. Günther, R. Castro, M. Curitol, A. L. Zanocco, J. Photochem Photobiol. A.: Chem. 2005, 175, 146-153.

[20] G. Bartoli, M. Bosco, A. Carlone, A. Cavalli, M. Locatelli, A. Mazzanti, P. Ricci, L. Sambri, P. Melchiorre, Angew. Chem. Int. Ed. 2006, 45, 4955 4970.

[21] a) A. Mauger, J. Farjon, P. Nun, V. Coeffard, Chem. Eur. J. 2018, 24 4790-4793; b) L. Huang, J. Zhao, S. Guo, C. Zhang, J. Ma, J. Org. Chem. 2013, 78, 5627-5637.

[22] For similar mechanism, see: Y. Wang, T. Xiong, Q. Meng, Tetrahedron 2015, 71, 85-90. 
[23] E. Balmond, B. K. Tautges, A. L. Faulkner, V. W. Or, B. M. Hodur, J. T. Shaw, A. Y. Louie, Org. Lett. 2016, 81, 8744-8758

[24] I. D. Jurberg, Chem. Eur. J. 2017, 23, 9716-9720.

[25] E. C. Aka, M. C. Nongbe, T. Ekou, L. Ekou, V. Coeffard, F.-X. Felpin, J. Environ. Sci. 2019, 84, 174-183.

[26] A. M. R. Smith, D. Billen, K. K. Hii, Chem. Commun. 2009, 3925-3927.

[27] D. Steinhilber, T. Rossow, S. Wedepohl, F. Paulus, S. Seiffert, R. Haag, Angew. Chem. Int. Ed. 2013, 52, 13538-13543.

[28] M. Yuan, X. Yin, H. Zheng, C. Ouyang, Z. Zuo, H. Liu, Y. Li, Chem. Asian J. 2009, 4, 707-713. 